\title{
Corporate Governance Practices in India: Evidence from INFOSYS Ltd.
}

\author{
Pradip Kumar Das \\ J.K. College, Purulia, India \\ Email.: pradip57.prl [AT] rediffmail.com
}

\begin{abstract}
Corporate governance has been growing concern in view of acclaimed turpitude gripping molest of corporate power by governor. Superb governance ferments for the welfare of all involved by cinching that the undertaking upholds universal ideals, proven approach and ordnance. Infosys in ITC sector harmonizes with corporate governance in the Indian corporate domain. This paper basically concentrates on how corporate governance of Infosys, the selected companyprecipitates its sustainable headway. The study is descriptive in nature and mobilizes secondary data for the purpose. The results proffer that corporate governance is a device of selfappraisal for the company which eventually emanates its sustainable survivability.
\end{abstract}

Keywords--- Corporate governance, board, corporate, stakeholders

\section{INTRODUCTION}

Salubrious corporate governance( or CG) exercises are erstwhile mandate but haveembellis hed necessit ous for much subsis tence of a concern. CG arrests s windles having colossal affinity on the close-in shareholders as well on the hope of the vast stakeholders. It exerts exemplary practices and has abidance to elevated excellence for stewardship and stable growth of all relevant parties in society. In India, CG barraging on strategy shapes the techniques of behaving towards stakeholders and corporate performances. Good CG proffers impetus for the board to dog intentness seamlessly for the sake of the corporation. This paper shows a study of CG practices in India with the help of an illustration of a leading IT sector company, Infosys Ltd. CG in this company ensures fairness for every stakeholder of the countries in which it operates and leads in benchmarking CG policies across the world.

\section{CG-CONCEPT}

CG is a matter of regulatory compliance, an annual ritual with checkboxes and not as a practice resulting in su perior market valuations. It refers to the range of institutions and practices by which authority is exercised to $s$ atisfy the nee ds of all stakeholders in the society and its meaning is fashioned by the specific value systemprevalent in the country. A good CG model ens ures fairness, civility and excellence in all transactions to manage corporate bonafide to maximize its long-term value for all.

\section{INFOSYS -AN INTRODUCTION}

Infosys Limited, an Indian Information Technology Company(ITC)headquartered in Bengaluru, Karn ataka, In dia was established in 1981 with an initial investment of US \$250. It imparts all-embracing management consultant and infote ch facilities. Infosys serves about 45 countries by way of devising and implementing multiple computerized techniques, and rejuvenates differentes tablishments to attain dexterity. This worldwide appreciated corporate provides superb business solutions utilizing technology extricated by distinguished people. FICO score (credit score) of Infos ys is A -(rating by Standard and Poor).Infosys' leading position captioned as an Asian invasion in the rankings(Forbes India Magazine,2020) and graded $3^{\text {rd }}$ in the world among the best companies, 2019 based on its solidity, honesty, etique tte, justness to its employees and the accomplishment of its products and services which instantiates the company's culinary masterpiece, the veneration it enkindles amongst its stakeholders and also illuminates the commitment of universal technological services(Forbes American Bus iness Magazine,2020).

\section{LITERATURE REVIEW}

CG involves cognation within multi-parties of corporate and boosts shareholders insite sustainably to validate equity to different relevant parties(Bhattacharya,2007).CG makes directors accountability to investors for stewardship of corporate 
in its vigorish and als o commensurate for ideology(Prakash,Neetu,2007). Good CGattributes assist corporate to function properly through multi-audit committee methodologies(Bhasin,2012).Study on CG towards rising economy is vital. Substantial gains of improved CGmodes can be observed(Claessens and Yurtoglu,2013). Schwartzanalyse s man agers perception on 'business ethics' and associates it with ethical behavior and non-ethical behavior(Schwartz,2012). CG does not merely maximize shareholding; on the other hand, it embraces collaboration among the concerned parties and the ends whatfor the corporate is regulated(Corporate Governance, 2011) Convergence of CG and CSR doctrine is viewed as an innovatory shift bringing decentralization of s tatu tory authority fromone sector to other. Convergency between CG and CSR bestows budding occasion for corporate functioning in all territories, advanced and advancing (Rahim\&Alam,2014). A positive perception of humanism might accentuate ideological amelioration and pragmatic relevance of unworldly postulate of CG such as regulatory framework(Francoeur,et.al.,2015).Empirical evidence suggests that combined CEO and chairperson personage improve CG for solidarity and close monitoring (Krause, et.al.,2014).Policy makers caption the approach of sociocultural context drives coordination inside corporate policymaking techniques(Passetti,et.al.,2014).

\section{OBJECTIVE OF THE STUDY}

Installation of sound CG into the culture of corporate has become absolutely necessary for developing an overall environment in corporate sector. The basic objective of the study is to examine how CG practice of the top Indian IT sector company has precipitated to the society and how this has fostered in its long-terms ustainability.

\section{MATERIALS AND METHODS}

In an attempt to meet the objective put forward in this study, the author has gathered data from the reports publis hed on corporate website. This study is descriptive in nature and has used mostly secondary data like books, journals, web sites, etc. The study confines to the period of 6 years i.e. from 2015 to 2020 as the data beyond this period is not systematically accessible. Hence, the conclusion drawn from the study is also limited to this period. Out of $15 \mathrm{~s}$ ample companies in India from different sectors, Infosys, a top IT sector company has been selected for the study for its significant achievement in genuine corporate social responsibility (or,CSR) activities and others through s ound CG which help the company attain long-term sustainability. Other considerations are that Infosys stood $1^{\text {st }}$ position in the Indian Companies List,2019based on its performance in four metrics like sales, profits, as sets and market (Bus iness World Issue,2020).Stratified random technique tool is used for selecting the sample unit. Besides descriptive study, the res earcher als o conducted survey study with the help of is sue of questionnaires, etc. Dis cussions and personal intervie ws with the staffs and the concerned authorities of the company were undertaken by the researcher. On-the-spot studies were carried out with the help of well-structured questionnaire. Tentative questionnaires were pre-tested with the staffs and authorities.

\section{CG POLICIES}

Infosys's CGrests on sound principles and not just follows its wording but also contributes much to the essence of law and upholds pellucidity. Besides following global best practices, CG policies of Infos ys bring valuable pragmatismto the board.

\section{CG Guidelines}

\section{i. Purpose and Frame work}

Strong CG is the backbone of substantiality at Infosys. CG standards contribute a foundation for board to adroitly pursue the corporate mis sions supporting stakeholders supposing its Memorandumand Articles of As sociation, Charters, regulations applicable in India, USA and other jurisdictions.

\section{ii. Board Structure and Composition}

\section{a. Board Size}

Board size of Infos ys eyes Memorandumand Articles of Association, CompaniesAct,2013,SEBI(Listing Obligations and Dis clos ure Requirements)Regulations,2015 and such other regulations in force. Board has always a minimu m of on e female independent director with a optimal mixture of executive, non-executive and independent directors. Nonexecutives anyway occupy half of the board members to respect various laws. Board has no fixed policy behind the selection of the Chair from the directors or any other members. Roles of Chairperson and CEO are clearly demarcated.

\section{b. Board Diversity}

Because of global characteris tics, Infosys considers diversity of thought, perspective, knowledge, skill, cu ltu re, etc. in evaluating candidates. Nomination and Remuneration Committee built on aboveparameters defines standards u nder Board Diversity Policy and recommends candidates in the board for its shareholders approval. 


\section{c. Lead Independent Director}

Independent directors appoint Lead Independent Director convenient to the comp any to en sure rob ust in de pendent leadership, authority and res ponsibility on the board. Lead Independent Director serves as a liais on be tween the nonexecutive directors and management, and performs such more duties as the board determines.

\section{d. Director Elections}

One third of the Board members retire by rotation. Members willing to get re-appointed are elected by the shareh old ers on the recommendation of the board at the annual general meeting. Independent directors do not retire by rotation due to their appointment for specific term.

\section{Board Qualifications and Term}

\section{i. Key Board Attributes and Expertise}

$>$ Board consists of distinguished individuals with broad perspectives on global market opportunities for worth while contributions to the board and its committees.

$>$ Dexterity in financial management and fin ancial reporting process in overseeing principal financial officer.

$>$ Practical perception of org anizations, stratagemand hazard management.

$>$ Burliness about skill-building, programprogression, bringing transformation and sustainability.

$>$ Significant credentials to anticipate technological trends, generate high-tech and fabricate new business models.

$>$ Potentiality to appraise 'build or buy' decisions, coalescing the target with strategy, meticulously value transactions and gauge operational plans.

$>$ Developing perspicacity about purporting board and management culpability, sheltering shareholders clique and eying apposite proven approach.

$>$ Knowledge in cultivating strategies for business development, brand awareness and strengthening enterprise celebrity, etc.

$>$ Knowledge of building and squiring impregnable concerns.

> Deciphering graveness of the environment, social, governance ('ESG') goals, and their impres sion on the boards role, configuration and workflow.

\section{ii. Board Independence}

Board contains majority of directors touching the benchmarks for independence by the Act and critiques the coterie each director has with the company. Thus, the directors having no material coterie is only ruminated Independent Directors.

\section{iii. Term Limitations and Retirement Policy}

Term of executive directors does not exceed five years on each hap. An independent director holds office for a term up to five consecutive years and may be reappointed for another termup to five years by special resolution. The company does not appoint or continue the employment of any individual as Managing Director or Executive Director aged sixty years and does not appoint or continue the directorship of any individual as non-executive or In depen dent Director ag ed seventy years. Board at its discretion with the approval of shareholders may appoint or extend the specified age limit by special resolution based on explanatory statement annexed to the notice indicating the justification for such appointment/extension.

\section{iv. Specific limitation on other Board Service}

Executive directors may with prior consent of the Chairman serve on the Board of two other business en tities if such entities are not in direct competition with the company's operations. Executive directors can als o serve on the Board whose interests are germane to the future of the information technology and the key economic institutions of the nation to benefit society. Independent directors cannot serve on the Boards of contesting companies. Director's commitment d oes not materially interfere with Director's service and is consistent with the company's conflict of interest policy.

\section{Board Inductions}

\section{i. Screening and Selection of New Directors}

Board delegates screening and selection process of new directors to Nomination and Remuneration Committee. Committee formulates criteria for qualifications, optimis tic perception and liberty of Director and advocates candidates to the board. 


\section{ii. New director orientation and continuing education}

Board believes ongoing education for effective board. Infosys hosts orientation programfor fresh directors that co vers introduction to the company's Key Managerial Pers onnel(KMP)and organization structure, services, group structure a nd subsidiaries, constitution, board procedures, etc. Incumbent directors can also attend orien tation pro gram. Execu tiv e directors or other senior managerial personnel present an overview of strategy to familiarize new inductees of the company. Independent directors attend CG-related educational program.

\section{Roles and Responsibilities of the Board}

Board with fiduciary res ponsibility en sures cleargoal aligned to shareholders value and growth. Setting strategic g o als , Board corroborates stakeholders aspirations and societal expectations. While grooving oblig ations, direct ors tru st in honesty and probity of the officers, employees, independent auditors and other advisors. Further, members have allacces s to the company's records. Directors obey the company's code of conduct and ethics.

\section{i. CG Philosophy}

Board exerts discernment in its fiduciary capacities to perceive company's governance philo sophy. CG enco mpas se s culture, policies and relationships with stakeholders. Solidity and limpidity are crux to CG practices to corroborate the credence of s takeholders.

\section{ii. Conflict of Interest}

Board members are mindful of likely conflicts of interest that can impair theirindependence and discuss any is sue with the Chairman and the Lead Independent Director. If significant conflict arises and remains unresolved, director is expected to resign. Each director requires disclosing their details to the company. Audit Committee reviews all related party transactions as required under company's party transaction policy, laws of India and regulations framed by the US Securities and Exchange Commission and the NYSE.

\section{iii. Material Non-Public Information}

Board members by virtue of their positions, expose material, non-public information, s trategy and operating plans. They treat information confidentially and are prohibited from discussing any information having bearing on share price of the company, with friends, relatives and acquaintances until such information is executed or evacuated. Members are proscribed fromhedging activities and explicitly support the Insider Trading Policy of the company.

\section{iv. Corporate Citizenship and ESG Efforts}

As overseers of risk and stewards of long-termenterprise value, board assesses the company's environmental and s ocial impacts. Board is also responsible for the impact and related risks of ESG issues on the operating model like understanding, implementing, reporting ESG, etc.

\section{v. Consideration towards Stakeholders and Transparency}

Board contemplates the impact of various decisions on the company's stakeholders and discloses cle arly all direct or indirect matters affecting them.

\section{vi. Risk Management Oversight}

Board oversees management's efforts to mitigate risk. Board reserves oversight of major risks and delegates risk responsibility to board committee. Risk Management Committee assists board in fulfilling its CG oversight res ponsibilities. Committee monitors and approvs risk management framework and associated practices of the company.

\section{vii. Strategic and Operating Plans}

At least once a year, board holds a strategy retreat where the members of the leadership team present the overall corporate strategy and seek inputs fromboard. Board regularly monitors theimplementation of the annual plan s and at next meetings reviews the performance against strategic plan. Besides, board reviews s pecific strategic initiatives o ver the year and provides judgment on important is sues.

\section{viii. Meeting Attendance}

Board members attend at least four board meetings, committee meetings and annual general meetings of the shareholders in a year. However, in case independent directors fail to remain presencephysically at the meeting, the company arranges video conferencing or any other audio-visual means for their participation. Members devote powwow in meeting s to dis charge their commitments. Prior to meetings, directors review meeting materials and communicate any question they desire to dis cuss so that management is prepared for the same. 


\section{ix. Governance Controls}

Board approves committees, composition of board, working procedures and encourages directors training. It als o select s independent auditors, monitors financial information and legal compliances. Board reviews meeting on s pecific matte rs, budget, major capital expen ditures, acquisitions, different corporate activities, etc. In unforeseen exigency, CG en s u res the best possible outcomes for all s takeholders. Board oversees the management of cris is events and directly manages the crisis emerging fromgovernance. Board advises management for any mitigation actions. Upon the end of cris is, b o ard executes what are learnt fromexperiences. Nomination and Remuneration Committee reviews de velopment prog ram with KMP and other members, and periodically evaluates corporate policies, plans, procedures, etc. apropos of succession planning.

\section{Board Com mittees}

Board's Standing Committee forms committees representing board members or executives and delegates responsibilitie s to committee as per law. Configuration honors then-current Act, Regulations, NYSE conditions and such other laws/regulations concerning the company. Further, committee membership follows the criteria of overall committee members hip across all public limited companies prescribed under listing regulations. Board designates committee's chair and sporadically devolves assignments as prescribed under law. Charter is available in the website in details. Each committee submits its annual report highlighting the activities undertaken by themduring the year and evaluates its performance to assess efficacy. Nomination and Remuneration Committee facilitates evaluation. An external s pecialis $t$ engaged by the Board/Committee executes the evaluation.

\section{Board Operation and Meeting}

\section{i. Meeting Schedule and Place}

Board meets at least once a quarter and may als o meet at such other times according to schedu le and place circulated to every member in advance in office or in any other designated place and members can participate through video conferencing if the prevailing laws permit. Independent Directors can arrange for separate meeting in a year for evaluating and assessing their accomplis hments which are essential to reasonably performtheir duties.

\section{ii. Agenda}

Agenda for meeting are widely circulated amongst the members including chairperson for reviews, if any. Members can suggest for inclusion and exclusion of items in the agenda. They can raise at meeting outside the agenda with the permis sion of the Chair and consent of the majority of directors.

\section{iii. Distribution of Agenda and Meeting Materials}

Agenda and meeting materials are sent to directors prior to board meeting excepting matters concerning material, unpublished and price sensitive. Objective must permit adequate time for discussion precisely between board members and management for successful managerial decision making purpose. They have unfettered approachability to books of accounts and can also hire counsels and experts at the cost of the company to obtain advice, reports or opinions at their sole dis cretions. Non- board members can als o participate to answer any query on certain aspect.

\section{Performance and Compensation}

\section{i. Board Evaluation}

Nomination and Remuneration Committee formulates criteria for board evaluation with a view to strengthening potency. An external specialist may also be engaged to carry out the evaluation. Committee ens ures smooth conduct of evaluation process and specifically stresses areas where the board and/or management thinks improve ment is desirable. While recommending a director for re-election, committee considers directors participation at meetings and contribution to the board. The committee assesses Chief Executive Officers which, in turn, as sess Key Managerial Personnel(KMP) ba sed on Key Performance Indicator(KPI). Total shareholders return(TSR) is used in decision about the compensation of Chief Executive Officer(s) and KMPs.

\section{ii. Board Compensation}

Nomination and Remuneration Committee determines board compensation pursuant to all laws and principles of the charter with close long-terms hareholders interest. Independent directors are without any stock incentives for their services on board. Executive directors do not have any sitting fees in meeting. 


\section{Shareholder Relations}

\section{i. Engagement with Shareholders}

Infosys maintain active dialogue with shareholders and ensures that substantiveinformation disparity stems not amongst shareholders. It also provides explanations on various items covering the basic principles of capital policy, manag ement strategy, operating plans, management benchmarks and resources.

\section{ii. Protecting Shareholders Rights and Interests}

To protect shareholders rights, Infosys appropriately discloses all material information to sharehold ers affe cting their investment decision and als o gives due consideration to the rights of minority shareholders. Board me mbers, KM Ps or any officer of the company do not conduct any transaction that conflicts or competes shareholders in terest without board's approval.

\section{Miscelleneous}

Board, in its discretionary power, has every right to periodically review the CGguidelines wholly or partly. If any discrepancy aris es regarding rules, laws, provisions of such other law relevant to the company, etc., statutory provis ions eclipse this guideline. Any subsequent amendment in the enactment automatically applies in the matter.

\section{RECOMMENDATIONS}

- Management should endeavor to ensure right direction of CG process and generate collective su pport with in the company.

- Infosys should reflect the confidence of management stressing management should do what it promises. Consistency between verbal and non-verbal affairs of the corporate is desirable.

- Infosys should show respect and courtesy to all stakeholders with positiveoutlook and motivational activities.

- Constant endeavor requires accompanying commonness between different stakeholders and society at large.

- Infosys should stay focused in proving good governance that means good business in the long run.

- Stakeholders should be updated about CGin the draft phase to make it effective.

- There should be continuous searching process for global governance and development of social market economy and method to integrate sustainable ethics.

- An extended governance model containing corporate culture, legal en vironment and the liveliness of the members of civil society in putting CG at the top of the corporate agenda is crying need of the hour.

- Efforts must be made to resolve the ambiguities in the provisions concerning CG to ensure adoption of healthy practices by the company.

- Investors education and awareness for more participation and deliberation at meeting is desirable.

- Independent directors should take periodic training on the various as pects of identifying, analyzing and pre venting abusive activities. Their appointment should be under strict binding regulation.

- Value of intangible assets like trust, loyalty, honesty, etc. will obviously increase with the acceptance of sound CG.

- Infosys must sustain hearty relationship with the ever-growing number of stakeholders demanding share of benefits from the business with good CG.

- Effective CG becomes imperative for company to share the responsibilities for distributive justice and inclusive growth.

- Favorable environment will certainly focus more openness towards the practice of CG.

- More understanding about the ideological as sociation between CGand CSR helps merge these two constructs.

- Experts should prepareCG reports with reference to utility, cost and contents of the details disclosed by Infosys to reduce box-ticking exercise and enhance the quality of the governance.

- Regulators are to be more vigilant to curb any plundering practices in Infosys. Although thenew Act has strengthened the provisions, speedy disposal of cas es concerning corporate offences is desirable.

- Risk taking is a driving force for any corporate. Cost of management failures and time is still externally and internally underestimated. CG should ensure that risks are understood, and, if appropriate, communicated.

- ForCG, Infosys rather than mere compliance should focus more on internal ethical code to increase tran sparency, accountability, fairness and independence.

- There are many regulators supporting CG application; harmonization of the decision making centers is one of the initial difficulties.

- The Government should promoteprofessionalism and independent functioning of the board in corporate. 


\section{CONCLUSION}

Los s of public trust censed by unethical CG worsens corporate-society relations and calls for rock-hard multi-s takeholder governance adverse to the current mono-stakeholder governance. Board must be in the vanguard of stakeholders governance to assert its role as trustees and creators of socially responsible corporate. Conscious efforts to wards s ound CG arrest deteriorating political and social values. There should be multidis ciplinary approach to teach, train and practice CG. Understanding of the core values of CG creates growing attention towards democracy and capitalis $\mathrm{m}$, b o th in the economy and in the political arena. Society arrests decay in socio-economic sphere with the help of CG to tackle uns ustainable behavior. Achievement is challenging. Nobody can stay unconcerned, rather, efforts should be unfaltering to devote in the best possible means to make CG success(Visser,2004).CG and sustainable amelioration always synthesize as the company contemplates to perdure for perpetuity and thereby, it feathers the society for future development. As an Indian company, it staunchly accredits corporate responsibility to upgrade the modus vivendi and reform the walk of life of society where it operates.

\section{IMPLICATION OF THE STUDY}

$\mathrm{CG}$ is an important mechanism to cultivate culpability in corporate especially with the rapid globalization and the emerging trend towards free economy. This forumreconnoiters important exemplars on CG practice as a control de vice to achieve sustainability. This paper draws on Infosys's experience to establish basic principles that need to be contemplated when developing an institutional set-up for implementing CG of this nature. In fo sy s's CG is bas ed on stakeholders perceptions of its social impact and their evaluation for ethical performance. Thus, corporate must perceive the necessities and proclivities of CG and then mold its spirit for their satiety.

\section{CONCLUDING COMMENT}

Good CG not only makes corporate lives better, but the lives of various stakeholder groups too. Society, at large, may in the long-termbecome better off in a holis tic sense, not only commercially but in terms of overall well being.

\section{FURTHER STUDY}

The paper is developed on dis tinct ITC sector company. The exploratory study may further be elev ated taking a great number of companies of other sectors ingrained on their CG strategy to disseminate the conclusion. The re searcher adjudges that the prospect in this sphere demands extensive study to clinch at more meaningful conclusion and hopes that other possible conditions for CGideology will be extricated by future studies.

\section{REFERENCES}

[1] Bhasin, M., Audit Committee Mechanism to Improve Corporate Governance: Evidence froma Developing Country, Modern Economy, vol. 3, no.7,pp.856-872, 2012.

[2] Bhattacharya, Sumita, Stakeholders' Wellness, Portfolio Organizer, pp. 51-54, 2007.

[3] Business World Is sue, 2020.

[4] Claessens, S. and Yurtoglu, B., Corporate Governance in Emerging Markets: A Survey, Emerging Markets Review,pp. 151-33, 2013.

[5] Corporate Governance, http://en.wikipedia.org/wiki/Corporate_governance-07-620, 2011.

[6] Forbes American Business Magazine, 2020.

[7] Forbes India Magazine, 2020.

[8] Francoeur, C., Melis, A., Gaia, S. and Aresu, S., "Green or Greed? An alternative look at CEO Compens ation and Corporate Environmental Commitment”, J. Bus. Ethics, pp. 1-15, 2015.

[9] Krause, R., Semadeni, M. and Cannella, A. A., “CEO Duality: A review and research agenda”. J. Manag., vol. 40, pp. 256-286, 2014.

[10] Pas setti, E., Cinquini, L., Marelli, A. and Tenucci, A., "Sustainability Accounting in Action: lights and shadows in the Italian context”, Br. Account. Rev., vol. 46, no. 3, pp. 295-308, 2014.

[11] Prakash, Neetu, “Corporate governance in Asian Nations”, Indian Journal of Accounting, vol. XXXVII, no. 2, pp.27-34, 2007.

[12] Rahim, M. M. and Alam, S., "Convergence of corporate social res ponsibility and corporate governance in we ak economies: the case of Bangladesh”, J. Bus. Ethics, vol. 121, no. 4, p.6, 2014.

[13] Schwartz, M., The state of business ethics in Is rael: a light unto the Nations"? J Bus Ethics, vol. 105, pp. 429446, 2012.

[14] Vis ser, Wayne, Analysis-FiveCorporateSustainability Challenges that remain Unset, ECNewsdesk, 2004. 